УДК 619:616.99.3:615.35:636.4

(C) 2017

Свстаф'єва В. О., доктор ветеринарних наук, професор,

Мельничук В. В., кандидат ветеринарних наук, Манойло Ю. Б., асистент

Полтавська державна аграрна академія

\title{
ЕФЕКТИВНІСТЬ ЗАСТОСУВАННЯ ФЕРМЕНТНО-ПРОБІОТИЧНИХ ЗАСОБІВ ЗА ДЕГЕЛЬМІНТИЗАЦІї СВИНЕЙ
}

\author{
Рецензент - доктор ветеринарних наук, професор А. А. Замазій
}

Представлені результати наукових досліджень щзодо вивчення ефективності застосування сучасних ферментно-пробіотичних засобів у поєднанні із антигельмінтним препаратом за спонтанного езофагостомозу свиней. Встановлено, щзо використання пробіотика та ферменто-пробіотичного засобу у прочесі проведення дегельмінтизачії підвищує інтенсефективність антигельмінтики «Бровермектина $2 \%$ водорозчинного», скорочує терміни одужання інвазованих свиноматок та сприяє підвищенню середньодобових приростів маси тіла поросят $i$ збереженості поголів'я молодняку.

Ключові слова: свині, езофагостомоз, лікування, ефективність, «Бровермектин $2 \%$ водорозчинний», «Вітаиел-Ф», «Емпробіо».

Постановка проблеми. Пріоритетними завданнями розвитку агропромислового комплексу України є забезпечення населення високоякісними продуктами харчування тваринного походження, підвищення конкурентоспроможності тваринницької галузі та гарантування продовольчої безпеки держави. Аналіз сучасного стану свинарства свідчить, що важливими перешкодами на шляху розвитку цієї галузі є кишкові нематодози. 3 них провідне місце займає езофагостомоз - захворювання, що має значне поширення як на території України, так і за ії межами $[2,3,4]$.

Тривале паразитування нематод у свиней викликає порушення обмінних процесів, імуносупресію, відставання в рості й розвитку, втрату маси тіла [7]. Все це призводить до зростання виробничих витрат: збільшення періоду відгодівлі, зменшення середньодобових приростів, зростання конверсії корму, витрати на закупівлю ветеринарних препаратів [5].

На сьогодні використання кормових добавок iз застосуванням пробіотиків та пребіотиків $€$ найбільш ефективним засобом для лікування i профілактики хвороб шлунково-кишкового тракту свиней, а дослідження ефективності сучасних препаратів у разі езофагостомозу за допомогою кормових добавок $є$ перспективним напрямом наукових досліджень.
Аналіз останніх досліджень і публікацій, у яких започатковано розв'язання проблеми. Езофагостомоз відносять до числа найбільш розповсюджених кишкових нематодозів свиней [6]. Патогенний вплив езофагостом на організм свиней складається 3 місцевої механічної і токсичної дій личинок цих паразитів на стінки товстих кишок. Одночасно на пошкоджені личинками тканини впливають і продукти життєдіяльності мікроорганізмів, яких інокулюють личинки езофагостом із просвіту кишечника в товщу його стінки [9].

Доведено, що гельмінти негативно впливають на нормальну мікрофлору організму хазяїна, викликаючи дисбактеріоз, який ускладнює перебіг паразитарного захворювання і нерідко обумовлює тривалу дисфункцію кишечника. Одним із факторів, здатних активізувати вплив умовнопатогенних мікробів на організм тварин, $є$ нематоди, зокрема збудник езофагостомозу [1].

Нормалізація складу мікрофлори кишечника сприяє звільненню свиней від нематод. Однак процес відновлення мікрофлори шлунковокишкового тракту тривалий. Тому окремі науковці для скорочення термінів відновлення мікрофлори шлунково-кишкового тракту тварин пропонують застосовувати пробіотики - природні ад'юванти, живі мікроорганізми, введення яких в організм тварини та людини сприяє підтриманню і відновленню біологічного балансу його нормофлори та має позитивний ефект. Вони також дають можливість усунути явища дисбактеріозу, який виникає за рахунок використання антигельмінтиків, і сприяють якнайшвидшій нормалізації мікрофлори кишечника та його функціональної діяльності [8].

На підставі вищевикладеного можна зробити висновок, що комплексний підхід до проблеми езофагостомозу і спричиненого ним дисбактеріозу дає змогу більш успішно проводити заходи, спрямовані не тільки на ліквідацію інвазії, а й на нормалізацію мікрофлори кишечника хворих тварин. 


\section{ВЕТЕРИНАРНА МЕДИЦИНА}

Мета досліджень - визначити ефективність сучасних препаратів за езофагостомозу свиней.

Основним завданням було вивчити показники збереженості та продуктивності поросят у випадку лікування свиноматок, хворих на езофагостомоз із застосуванням антигельмінтних препаратів та ферментно-пробіотичних засобів.

Матеріали і методи досліджень. Дослідження проводили впродовж 2015-2016 рр. в умовах ТОВ «Октан» Зіньківського району Полтавської області на супоросних свиноматках української білої породи, спонтанно інвазованих езофагостомами (II - від $876,8 \pm 19,93$ до $889,6 \pm$ 28,44 ЯГФ).

Були сформовані три дослідні і дві контрольні (хворі та клінічно здорові свині) групи по п'ять голів у кожній. Свиноматкам препарати задавали за місяць до опоросу.

Свиням першої дослідної групи випоювали груповим способом «Бровермектин $2 \%$ водорозчинний» у дозі 1 мл/50 кг маси тіла одноразово. Розраховану для всього поголів'я дозу препарату розводили в одній третині добової норми питної води та випоювали упродовж однієї доби.

Свиням другої дослідної групи випоювали груповим способом «Бровермектин $2 \%$ водорозчинний» у дозі 1 мл/50 кг маси тіла одноразово та одночасно застосовували пробіотик «Емпробіо», який задавали разом 3 питною водою у дозі 40 мл на голову 15 діб поспіль.

Свиням третьої дослідної групи випоювали груповим способом «Бровермектин $2 \%$ водорозчинний» у дозі 1 мл/50 кг маси тіла одноразово та одночасно застосовували ферментно-пробіотичний препарат «Вітацелл-Ф», який задавали разом 3 комбікормом у дозі 1 кг/т корму 30 діб поспіль.

Свиней контрольних груп не дегельмінтизували.

Ефективність антигельмінтика та у комплексному його застосуванні з пробіотиком і пребіотиком визначали на першу та 30 добу після опоросу в дослідних та контрольних групах свиней визначали: кількість поросят під час опоросу, масу тіла, середньодобові прирости та збереженість поросят.

Статистичну обробку результатів експериментальних досліджень проводили шляхом визначення середнього арифметичного (M), його похибки (m) та рівня вірогідності (p) з використанням таблиці t-критеріїв Стьюдента (С. Н. Лапач та ін., 2001).

Результати досліджень. 3 метою визначення ефективності випробуваних препаратів одночасно на першу та 30 добу після опоросу в дослід- них та контрольних групах свиней враховували наступні показники: кількість поросят під час опоросу, масу тіла, середньодобові прирости та збереженість поросят (див. табл.).

За результатами проведених досліджень встановлено, що препарат «Бровермектин 2 \% водорозчинний» виявився високоефективним антигельмінтиком за езофагостомозу свиней (EE, IE 100 \%), повне одужання свиней встановлювали на 14-ту добу експерименту. Отримані результати терапевтичної ефективності підтверджувалися і за показниками кількості поросят під час опоросу, маси тіла, середньодобових приростів та збереженості поросят, отриманих від свиноматок дослідних та контрольних груп.

Так, хоча і застосування «Бровермектину $2 \%$ водорозчинного» хворим на езофагостомоз супоросним свиноматкам призводило до підвищення вищезазначених показників на 20,69$26,75 \%(\mathrm{p}<0,05-0,01)$ порівняно 3 хворими свинями, яких не дегельмінтизували, водночас ці показники були нижчими на 3,33-28,92 \%, 12,50 ( $<<0,05-0,001)$ порівняно 3 клінічно здоровими свинями. Такі дані ще раз підтверджують те, що відновлення організму дегельмінтизованих тварин відбувається тривало і потребує комплексного лікування. За одночасного застосування хворим свиноматкам антигельмінтика і пробіотика «Емпробіо» показники кількості поросят під час опоросу, маси тіла, середньодобових приростів та збереженості поросят були вищими на 1,69-24,76 \% порівняно з аналогічними показниками у свиноматок, яким застосовували тільки «Бровермектин 2 \% водорозчинний».

За одночасного застосування хворим свиноматкам антигельмінтика та ферментнопробіотичного засобу «Вітацелл-Ф» показники, що визначалися, також були вищими, ніж у першій (на 6,37-36,86 \%) та другій (на 4,84$27,11 \%$ д дослідних групах і виходили на рівень показників у клінічно здорових свиноматок. Кількість поросят на одну свиноматку за народження становила 12,4 гол., на 30-ту добу 12 гол., збереженість поросят становила відповідно 96,8 \%. Загальна маса гнізда у свиноматок третьої дослідної групи становила 16,86 кг, на 30-ту добу - 170,9 кг. Жива маса поросят у свиноматок третьої дослідної групи становила за народження 1,34 кг, на 30-ту добу-14,24 кг. Середньодобові прирости поросят, отриманих від свиноматок після комплексного застосування антигельмінтика та ферментно-пробіотичного засобу, дорівнювали 430 г. 
Показники ефективності застосування сучасних препаратів у процесі лікування свиней, хворих на езофагостомоз

\begin{tabular}{|c|c|c|c|c|c|}
\hline \multirow{4}{*}{$\begin{array}{c}\text { Показники } \\
\text { ефективності }\end{array}$} & \multicolumn{5}{|c|}{ Групи тварин } \\
\hline & \multicolumn{3}{|c|}{ Дослідні } & \multicolumn{2}{|c|}{ Контрольні } \\
\hline & № 1 & № 2 & № 3 & & \\
\hline & $\begin{array}{l}\text { «Броверме- } \\
\text { ктин } 2 \% »\end{array}$ & $\begin{array}{l}\text { «Броверме- } \\
\text { ктин } 2 \% »+ \\
\text { «Емпробіо» }\end{array}$ & $\begin{array}{c}\text { «Броверме- } \\
\text { ктин } 2 \% »+ \\
\text { «Вітацелл-Ф» }\end{array}$ & хворі & $\begin{array}{l}\text { клінічно } \\
\text { здорові }\end{array}$ \\
\hline $\begin{array}{l}\text { Кількість поросят на од- } \\
\text { ну свиноматку, гол.: }\end{array}$ & & & & & \\
\hline за народження & $\begin{array}{c}11,6 \pm 0,50 \\
*\end{array}$ & $\begin{array}{c}11,8 \pm 0,37 \\
* *\end{array}$ & $\begin{array}{l}12,4 \pm 0,24 \\
* *\end{array}$ & $9,2 \pm 0,66$ & $12,0 \pm 0,44$ \\
\hline на 30-ту добу & $\begin{array}{c}9,8 \pm 0,48 \\
* \\
\text { a }\end{array}$ & $\begin{array}{c}10,8 \pm 0,37 \\
* * *\end{array}$ & $\begin{array}{c}12,0 \pm 0,31 \\
* * *\end{array}$ & $7,6 \pm 0,50$ & $11,2 \pm 0,2$ \\
\hline Збереженість, \% & $84,71 \pm 4,00$ & $\begin{array}{c}91,48 \pm 0,26 \\
* *\end{array}$ & $\begin{array}{c}96,79 \pm 1,96 \\
* * *\end{array}$ & $82,83 \pm 1,99$ & $93,71 \pm 2,89$ \\
\hline $\begin{array}{l}\text { Загальна маса гнізда, кг: } \\
\text { за народження }\end{array}$ & $\begin{array}{c}13,82 \pm 0,53 \\
*\end{array}$ & $\begin{array}{c}14,58 \pm 0,36 \\
* *\end{array}$ & $\begin{array}{c}16,86 \pm 0,48 \\
* * *\end{array}$ & $10,92 \pm 0,92$ & $15,16 \pm 0,82$ \\
\hline на 30-ту добу & $\begin{array}{c}107,9 \pm 2,67 \\
* * \pm \square\end{array}$ & $\begin{array}{l}143,4 \pm 2,04 \\
* * *\end{array}$ & $\begin{array}{c}170,9 \pm 4,82 \\
* * *\end{array}$ & $79,04 \pm 7,73$ & $151,8 \pm 6,74$ \\
\hline $\begin{array}{l}\text { Жива маса поросят, кг: } \\
\text { за народження }\end{array}$ & $1,19 \pm 0,06$ & $1,22 \pm 0,04$ & $\begin{array}{c}1,34 \pm 0,02 \\
* *\end{array}$ & $1,16 \pm 0,04$ & $1,24 \pm 0,04$ \\
\hline на 30-ту добу & $11,22 \pm 0,45$ & $\begin{array}{c}13,3 \pm 0,49 \\
* *\end{array}$ & $\begin{array}{l}14,24 \pm 0,14 \\
\quad * * *\end{array}$ & $10,38 \pm 0,57$ & $13,54 \pm 0,51$ \\
\hline $\begin{array}{l}\text { Середньодобові прирос- } \\
\text { ти, г }\end{array}$ & $\begin{array}{c}335,66 \pm 12,99 \\
\text {. }\end{array}$ & $\begin{array}{c}402,6 \pm 15,39 \\
*\end{array}$ & $\begin{array}{c}430,0 \pm 5,05 \\
* *\end{array}$ & $314,68 \pm 25,19$ & $418,6 \pm 23,13$ \\
\hline
\end{tabular}

Примітка: $*-\mathrm{p}<0,05 ; * *-\mathrm{p}<0,01 ; * * *-\mathrm{p}<0,001-$ відносно показників контрольної групи хворих тварин;

- $-\mathrm{p}<0,05 ; \boldsymbol{\square}-\mathrm{p}<0,01 ; \mathbf{\square}-\mathrm{p}<0,001$ - відносно показників контрольної групи клінічно здорових тварин.

\section{Висновки:}

1. «Бровермектин $2 \%$ водорозчинний» $є$ ефективним лікарським засобом за езофагостомозу свиней, водночас комплексне застосування антигельмінтика і ферментно-пробіотичних препаратів підвищує ефективність дегельмінтизації.

\section{БІБЛІОГРАФІЯ}

1. Довгий Ю. Ю. Особенности эпизоотологии нематодозов охотничей фауны на примере поголовья диких кабанов из Государственного лесоохотничего хозяйства «Дубенское» Ровенской области / Ю. Ю. Довгий, Д. В. Фещенко, В. Л. Бегас // Паразитарные болезни человека, животных и растений : тр. IV Междунар. научно-практ. конф. - Витебск, 2008. - С. 328-330.

2. Свстаф 'єва В. О. Асоціативні інвазії свиней в умовах Лісостепу і Степу України : автореф. дис. ... д. вет. н. : спец. 16.00.11 «Паразитологія» / В. О. Свстаф'єва - К., 2010. - 34 с.

3. Новая технология производства свинины с законченным циклом на собственных кормах /
2. Ферментно-пробіотичний засіб «Вітацелл$\Phi$ » та пробіотик «Емпробіо» за дегельмінтизації хворих свиноматок призводили до підвищення показників середньодобових приростів та збереженості поросят.

[Гегамян Н. И., Пономатев Н. М., Мошкутело И. В. и др.] // Свиноводство. - 2003. - №1. C. 17-21.

4. Рибалко В. П. Наукові аспекти розв'язання проблеми дефіциту свинини в Україні / В. П. Рибалко // Тваринництво України. - 2006. №2. - C. 2-4.

5. Сафиуллин Р. T. Система подготовки для паразитологических исследований «PARASEP» и ее апробация для диагностики гельминтозов свиней / Р. Т. Сафиуллин, С. К. Шибитов, А. В. Котков // Российский паразитологический журнал. - 2008. - №3 - С. 88-93.

6. Стибель В. В. Аналіз гельмінтологічної си- 


\section{ВЕТЕРИНАРНА МЕДИЦИНА}

туації серед свиней у господарствах Львівської області / В.В.Стибель // Науковий вісник ЛНАВМ ім. С. 3. Гжицького. - 2004. - Т. 6, Ч. 1. - №2. - C. 197-198.

7. Шаполатов Ж. Клинический симптомокомплекс и формы течения экспериментального эзофагостомоза свиней / Ж. Шаполатов, Л. Дустова // Болезни сельскохозяйственных животных : труды УзНИВИ. - Т. ХXX, Ч. II. - Ташкент, 1981. - С. 105-113.
8. Шаполатов Ж. Ш. Паразитарные болезни свиней / Ж. Ш. Шаполатов. - Т. : Мехнат, 1987. $184 \mathrm{c.}$

9. Experimental Oesophagostomum dentatum infections in the pig: worm populations resulting from trickle infections with three dose levels of larvae / [ Roepstorff A., Bjwrn H., Nansen P. et al.] // Int. J. Parasitol. - 1996. Vol. 26 (4). - P. 399-408. 